\title{
Foreword
}

\section{John Walton (Lord Walton of Detchant)}

Having graduated in medicine in 1945 after a shortened wartime course in Newcastle Medical School, then part of Durham University, I had actually served for several weeks before graduation as a house officer, first in medicine with Professor F J Nattrass and secondly in paediatrics with Sir James Spence. These were two notable and outstanding teachers whom I admired greatly, and, after demobilisation from the Royal Army Medical Corps I returned to Newcastle to become a medical registrar, in order to obtain the MRCP qualification and more experience in general internal medicine. I was in a dilemma in deciding whether I should embark upon training for a career in paediatrics or in neurology, which was Professor Nattrass's principal interest even though he was Professor of Medicine. Ultimately, the decision was helped by the charismatic example of the late Dr. Henry Miller, Professor of Neurology in Newcastle and subsequently Vice-Chancellor of the University, whose inspirational example eventually persuaded me to choose neurology, even though I continued for many years to take an interest in paediatrics before a paediatric neurologist, my good friend the late and memorable Dr. David Gardner-Medwin, was appointed as our first paediatric neurologist. Hence, when I had completed my two-year medical registrarship, I was delighted to accept an invitation from Professor Nattrass to join him in order to carry out some research into the muscular dystrophies and other neuromuscular diseases as his research assistant. The remainder is history, since after surveying all the patients I could identify suffering from muscular dystrophy and other neuromuscular diseases in the northern region, I published with Nattrass in 1954 a paper in Brain on muscular dystrophy, introducing a new classification, and was then determined to spend such time as I could spare from my clinical duties in carrying out research into this group of diseases.

I was successful in applying for a Nuffield Foundation Fellowship, firstly to spend a year working with Raymond Adams at the Massachusetts General
Hospital in Boston, USA, where I learned a great deal about neuropathology and muscle pathology in particular, and then a second year in the National Hospital Queen Square in the Medical Research Council neurological research unit, headed by Dr. E A Carmichael. During my time in the USA, as a result of lecturing in many centres on the results of my clinical and genetic research, I was awarded a major research grant by the Muscular Dystrophy Association of America, which, on my return to the UK, enabled me to appoint a number of clinical research assistants, as well as individuals working in biochemistry, neuropathology and clinical neurophysiology, who contributed massively to our research programme. Happily, the research grant from the USA were followed by others from Canada, then from the embryonic Muscular Dystrophy Group, and later still from the Wellcome Trust and the Medical Research Council, which eventually awarded me a programme grant which I held for some 15 years.

At first, my research fellows were housed in a number of inconvenient locations in Newcastle University and its related hospitals, but when I was appointed a Consultant Neurologist in Newcastle General Hospital in 1958, I was able to persuade the Regional Hospital Board, as it then was, to add on to the Regional Neurological Centre then being planned, two floors of research laboratories in order to house my research programme. Later still, major donations, one substantial from an anonymous donor and others from supporters of the Muscular Dystrophy Group and local Tyneside benefactors, enabled me to build a block of muscular dystrophy research laboratories adjacent to the Regional Neurological Centre in order to expand our research programme. Work in Newcastle in all its aspects was greatly enhanced by the arrival of very many research fellows from countries across the world, including the USA, Australia, India and many parts of Europe, many of whom made outstanding original contributions to our field of work. These were halcyon days when many original contributions, based upon work done by my colleagues in the 
department, regularly appeared in peer-reviewed journals. We were very successful in obtaining a chair and seniorlectureshipinExperimentalNeurology, endowed by Action Research for the Crippled Child; the first holder was Dr. Walter Bradley, wholaterbecame Professor of Neurology in Miami. He and many other notable research fellows who spent time with me in Newcastle have generously given of their time to contribute to the symposium, the proceedings of which are published in the succeeding pages of this journal. My clinical colleagues, such as Dr. J B Foster, were very supportive, and David Gardner-Medwin did some excellent clinical and genetic research. I also remember with great pleasure and gratitude the major contributions made by Ken Pennington in neurochemistry, my close friend Professor (later Sir) Bernard Tomlinson in neuropathology, Peter Hudgson, Mike Cullen and John Fulthorpe in electron microscopy, Margaret Johnson in histochemistry, Louise Anderson in immunology, Alan McComas, David Barwick, Peter Fawcett and Clark Slater in neurophysiology, and, of course, Frank Mastaglia and John Harris, who followed Walter Bradley in the endowed chair. There were so many others who played important roles; Itrust they will forgive me for omitting their names (put it down to the failing memory of the aged).

When, in 1983 with a rather heavy heart, because of burgeoning national commitments, I left Newcastle to move to Oxford to become Warden of Green College, it continued to be a source of immense comfort to me to note the way in which the research programme on neuromuscular disease in Newcastle continued to develop and to prosper with outstanding success, led by so many of those, like the remarkable Kate Bushby, who have organised this symposium and who have honoured me beyond my wildest dreams by calling the research centre in the department of human genetics at Newcastle University at its Centre for Life the John Walton Centre for Research in Muscular Dystrophy. I am humbled but nevertheless deeply honoured in my 93rd year by this accolade, for which I am immensely grateful and also very proud.

John Walton, Belford Northumberland, May 2015. 